\title{
Counseling on Good Water Quality for the Cultivation of Batak Fish in Toba Lake Waters
}

\section{Penyuluhan Kualitas Air yang Baik untuk Budidaya Ikan Batak di Perairan Danau Toba}

\author{
Herna Febrianty Sianipar ${ }^{*}$, Theresia Monika Siahaan, Apriani Sijabat
}

Universitas HKBP Nommensen Pematangsiantar, Indonesia

\begin{abstract}
This service aims to provide information about the value of good water quality and demonstrate directly the tools used to measure it which aim to cultivate Batak fish based on biological, physical and chemical parameters such as temperature, dissolved oxygen, carbon dioxide, $\mathrm{pH}$, and provide information on the names of measuring devices. This service has been carried out in Gorat Village, Toba Samosir Regency with the method of counseling and material discussion (exposure and question and answer), as well as the practice of measuring water quality externally and analyzing the results of its value. The results of the counseling show that many fish farmers do not understand the value of good water quality for batak fish cultivation and not many know the equipment that can be used to check water quality. From this counseling, it can be seen that the interest of fish farmers and the community is very high, and they become more aware of the value of good water quality for fish farming and know the equipment.
\end{abstract}

\begin{abstract}
Abstrak
Pengabdian ini bertujuan untuk memberikan penyuluhan tentang nilai kualitas air yang baik dan mendemonstrasikan langsung alat yang digunakan mengukurnya yang bertujuan untuk membudidayakan ikan batak berdasarkan parameter biologi, fisika dan kimia seperti suhu, oksigen terlarut, karbondioksida, $\mathrm{pH}$, serta memberikan informasi nama alat-alat pengukurnya. Pengabdian ini telah dilakukan di Desa Gorat, Kabupaten Toba Samosir dengan metode penyuluhan dan diskusi materi (paparan dan tanya jawab), serta praktek pengukuran kualitas air secara eksitu dan menganalisis hasil nilainya. Hasil penyuluhan menunjukan bahwa banyaknya petani ikan yang belum paham tentang nilai kualitas air yang baik untuk budidaya ikan batak serta belum banyak yang mengetahui peralatan yang dapat digunakan untuk memeriksa kualitas air. Dari penyuluhan ini terlihat animo petani ikan dan masyarakat sangat tinggi, dan mereka menjadi lebih paham tentang nilai kualitas air yang baik untuk budidaya ikan serta mengetahui peralatannya
\end{abstract}

(C) 2021 Author(s)

Keywords: Tool; test; quality water, cultivation, counseling.

\section{Pendahuluan}

Danau Toba merupakan salah satu perairan umum yang terletak di Provinsi Sumatera Utara yang mempunyai luas perairan 112.970 Ha dan mempunyai potensi perikanan yang cukup baik untuk dikembangkan. Kawasan daerah danau Toba merupakan kawasan yang strategis dan dikelilingi 5 kabupaten yaitu Kabupaten Dairi, Karo, Simalungun, Toba Samosir dan Tapanuli Utara serta Humbang Hasundutan. Danau Toba terletak pada ketinggian sekitar 905 meter diatas permukaan laut. Keramba jaring apung adalah suatu wadah pemeliharaan ikan berupa kantong jaring yang

\footnotetext{
* Corresponding author:

E-mail address: hernasianipar54@gmail.com (Herna Febrianty Sianipar)
} 
letaknya terapung di permukaan air. Pemeliharaan ikan dalam keramba jaring apung tersebut merupakan kegiatan ekonomi masyarakat dengan memanfaatkan sumberdaya alam, tenaga kerja dan teknologi yang tersedia. Masyarakat tidak hanya berupaya memproduksi atau menghasilkan ikan untuk memenuhi kebutuhan rumah tangga saja, akan tetapi juga untuk memenuhi permintaan pasar. Selain itu tentunya juga dengan usaha tersebut diharapkan akan membuka lapangan kerja baru dan kesempatan berusaha bagi masyarakat (Suhadi dkk, 1989).

Pemasokan pakan ikan yang berlangsung terus menerus hampir ratusan ton/hari ke danau oleh para petaninya, telah menyisakan limbah yang mencemari kolom air hingga sedimentasi dasar danau. Selain pencemaran, sisa pakan juga dapat menyebabkan tingginya kekeruhan air yang mengakibat cahaya matahari akan susah menembus kolom air. Ahli lingkungan menggolongkannya sebagai permasalahan bencana non alam berupa pencemaran air danau dan rusaknya lingkungan alam sekitar. Banyak pemerintah daerah yang telah menerbitkan peraturan daerah atau kebijakan yang melarang digunakannya keramba jaring apung pada perairan danau; dan hal itu menimbulkan pertentangan yang menyangkut kelangsungan kehidupan petani budidaya ikan danau. Untuk menetralisasinya diperlukan sejumlah upaya akademik dan strategi pembangunan daerah yang bersifat kontekstual bagi perairan lingkungan danau (Andayani, 2005). Penerapan KJA untuk budidaya ikan di Indonesia dimulai dari konstruksi bangunan keramba yang sederhana. Di era modern sekarang ini, budidaya ikan tidak lagi membutuhkan tempat yang luas untuk dijadikan kolam pemeliharaan. Selain dipergunakan untuk budidaya ikan, KJA juga dapat dimanfaatkan untuk budidaya udang vanamae dan udang lobster.

Yang menjadi permasalahan pada budidaya ikan di keramba jaring apung adalah sisa pakan. Sisa pakan menurut Hardjamulia dkk, (1991), yang tidak terkonsumsi dan metabolik berupa senyawa nitrogen dan fosfor, apabila terbuang di kolom air dan tidak dimanfaatkan oleh organisme di sekitar danau (ikan, organisme bentik), maka akan menjadi partikel tersuspensi dalam bentuk partikel koloid di dasar perairan. Partikel tersebut akan dimanfaatkan oleh mikroorganisme khususnya bakteri untuk pertumbuhan dan perkembang biakannya.Selain pencemaran akibat nitrogen dan fosfor, sisa pakan juga dapat menyebabkan tingginya kekeruhan. Akibatnya, cahaya matahari akan susah menembus kolom air.

\section{Metode}

Penyuluhan dilaksanakan di Desa Gorat Kabupaten Toba Samosir, dan di KJA milik warga setempat, yang dihadiri lebih dari 25 orang. Metode yang digunakan dalam pengabdian ini adalah penyuluhan dan diskusi materi (paparan dan tanya jawab), serta praktek pengukuran kualitas air secara insitu (suhu, kecerahan, oksigen terlarut, $\mathrm{pH}$ dan $\mathrm{CO} 2$ ) dan menganalisis hasil nilainya. Sampel air yang digunakan diambil dari berbagai tempat sehingga dapat diketahui nilai kualitas air yang berbeda.

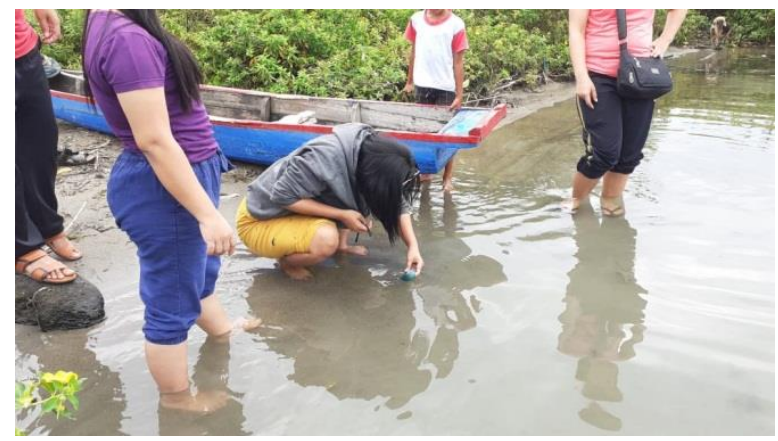

Gambar 1: Tim Pengabdi Mendemonstrasi Penggunaan Alat pH Meter

\section{Hasil dan Diskusi}

Hasil penyuluhan menunjukkan bahwa banyaknya petani ikan yang belum paham tentang nilai kualitas air yang baik untuk budidaya ikan serta belum banyak yang mengetahui peralatan yang dapat digunakan untuk memeriksa kualitas air. Oleh karena itu, penyuluhan dimulai dengan memberikan informasi (paparan) tentang parameter-parameter kualitas air yang harus diperhatikan dalam membudidayakan ikan beserta nilai-nilainya (Gambar 1). Ini merupakan langkah awal dalam membudidayakan ikan mengingat air merupakan media hidup ikan (Effendi,2003). 
Warga dan kelompok tani sangat antusias dan aktif dalam penyuluhan. Hal ini terbukti dengan pertanyaan-pertanyaan yang mereka ajukan ke tim pengabdian dan peserta yang hadir lebih dari 25 orang. Tim pengabdian penyampaikan materi secara terstruktur dengan menggunakan in focus serta memberikan keterampilan kepada warga dan kelompok bagaimana cara memeriksa kualitas air secara langsung (insitu) dengan menggunakan alat-alat kualitas air yang sudah disiapkan seperti DO meter, pH indikator, termometer, dan secchidisk (Gambar 3). Hasil analisis kualitas air secara insitu yang dilakukan tim pengabdian dan warga menunjukkan bahwa sampel air yang digunakan (dari keramba, KJA dan kolam ikan) bernilai normal $\left(28-31^{\circ} \mathrm{C}\right)$ sehingga dapat digunakan untuk budidaya ikan. Kisaran suhu optimal bagi kehidupan ikan di perairan tropis antara $28-32^{\circ} \mathrm{C}$ (Kordi dan Tancung, 2005). Derajat keasaman atau $\mathrm{pH}$ dari berbagai sampel air warga bernilai variatif dengan nilai 4-8. Menurut Marganof (2007), kisaran pH pada 6-9 merupakan nilai yang ideal untuk produksi perikanan. Kecerahan merupakan faktor yang dipengaruhi oleh cahaya yang masuk ke dalam badan perairan sehingga berpengaruh terhadap nilai oksigen terlarut. Selain kualitas air, faktor lain juga berpengaruh dalam membudidayakan ikan seperti faktor lingkungan dan pakan ikan. Untuk itu faktor lain juga harus diperhatikan untuk menghasilkan budidaya ikan yang optimal.

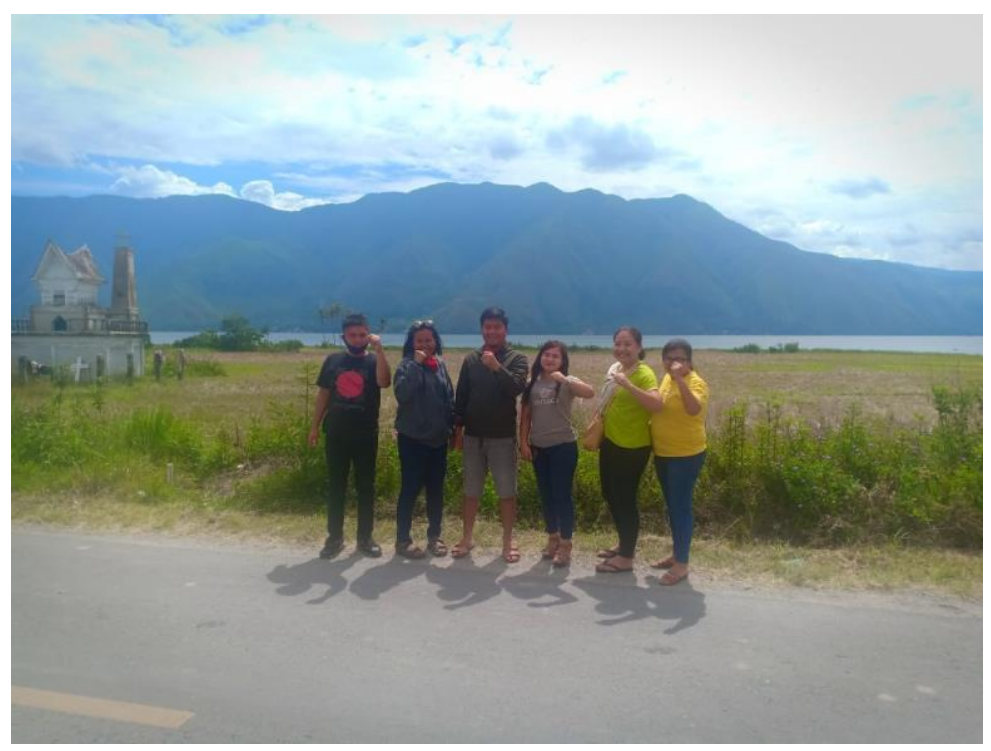

Gambar 2: Tim Pengabdi Bersama Masyarakat Dan Kepala Desa Gorat

Selama penyuluhan berlangsung semua warga dan kelompok tani desa Gorgat Kabupaten Tobasa mengikut rangkaian pengabdian dengan baik, antusias dan berperan aktif yang dimulai dari pemaparan materi, diskusi serta praktek. Penyuluhan kualitas air yang baik untuk budidaya ikan (parameter fisika kimia) telah dipahami dengan jelas oleh warga dan kelompok tani serta memahami pengoperasian beberapa alat kualitas air. Disarankan agar warga dan kelompok tani dapat memeriksa kualitas air terlebih dahulu sebelum memulai budidaya ikan dan selalu memonitor kualitas airnya. Warga dan kelompok tani dapat memiliki alat-alat kualitas air setidaknya alat yang paling sederhana atau yang mudah terjangkau seperti $\mathrm{pH}$ Meter karena harganya yang terjangkau, dan Termometer. Jika diperlukan sampel air dikirim ke laboratorium untuk diukur kadar Oksigen terlarut dan uji kandungan nuitrien yang terdapat pada air untuk mengetahui tingkat kelayakan air untuk budidaya (Fachrul, 2007).

\section{Kesimpulan}

Hasil penyuluhan menunjukan bahwa banyaknya petani ikan yang belum paham tentang nilai kualitas air yang baik untuk budidaya ikan batak serta belum banyak yang mengetahui peralatan yang dapat digunakan untuk memeriksa kualitas air. Dari penyuluhan ini terlihat animo petani ikan dan masyarakat sangat tinggi, dan mereka menjadi lebih paham tentang nilai kualitas air yang baik untuk budidaya ikan serta mengetahui peralatannya 


\section{Acknowledgements}

Penulis mengucapkan terima kasih kepada LPPM Universitas HKBP Nommensen Pematangsiantar yang telah memberi dukungan financial terhadap pengabdian ini.

\section{References}

Andayani S. 2005. Manajemen Kualitas Air Untuk Budidaya Perairan. Universitas Brawijaya. Malang

Hardjamulia, A., N. Suhenda, Krismono. 1991. Budidaya Ikan Air Tawar dalam Keramba Jaring Apung Mini. Pusat Penelitian dan Pengembangan Perikanan Jakarta.

Marganof, 2007. Model Pengendalian Pencemaran Perairan di Danau Maninjau Sumatra Barat. IPB. Bogor.

Suhadi, M.F., et.al. 1989. Petunjuk Teknis Budidaya Ikan dalam Karamba Jaring Apung. Badan Penelitian dan Pengembangan Pertanian. Pusat Penelitian dan Pengembangan Perikanan. Jakarta.

Effendi, H. 2003. Telaah Kualitas Air. Pengelolaan Sumberdaya dan Lingkungan Perairan Jurusan Manajemen Sumberdaya Perairan Fakultas Perikanan dan Ilmu Kelautan Institut Pertanian Bogor. Bogor.

Fahrul, M.F. 2007. Metode Sampling Bioekologi. PT. Bumi Aksara. Jakarta. Harmilia, E.D dan Khotimah, K. 2018. Kondisi Perairan Sungai Ogan di Ogan Ilir Berdasarkan Parameter Fisika Kimia. Jurnal Akuakultur Rawa Indonesia. Program Studi Budidaya Perairan. Universitas Sriwijaya. Hal 107-116.

Kordi, M.G.H.K. dan Tancung, A.B. 2005. Pengelolaan Kualitas Air. Rineka Cipta. Jakarta. Suwono, H.S. 2011. Berkala Perikanan Terubuk. Himpunan Alumni Fakultas Perikanan dan Ilmu Kelautan UNRI. Vol 39. No.2 Hal. 25-40. 